\title{
Demand and market pattern of selected medicinal plants in the southwestern Nigeria
}

\author{
Babatola OLUFEMI *, Amos AWOSUSI and Mathew BANJI OYUN \\ Department of Forestry and Wood Technology, Federal University of Technology P.M.B. 704, Akure, \\ Ondo State, Nigeria. \\ *Corresponding author, E-mail: olufemibabatola@yahoo.com; Tel: +234 8034734870
}

\begin{abstract}
Demand and market pattern of Aframomum melegueta K. Schum, Garcina kola Heckel, Senna alata (L.) Roxb., Tetrapleura tetrapetra (Schum \& Thonn) Taub., and Piper guineense Thonn \& Schum for medicinal purposes were carried out among the states in the south-western part of Nigeria with the study area comprising of Oyo, Ekiti and Ogun states. The population consisted mainly of Yoruba but mixed with other ethnic groups and foreigners who have settled down especially in the state capitals. Primary data were collected through a survey of the medicinal plants in the study area. Structured questionnaires were administered using the participatory method with the buyers and suppliers of the products. The result of the study showed that majority of the respondents $(64.79 \%)$ prefer daily market to other marketing patterns and over $80 \%$ of them offered all plant parts for sale. It was also discovered that the parts of medicinal plants sold depended on location.
\end{abstract}

() 2011 International Formulae Group. All rights reserved.

Keywords: Demand, Market pattern, Medicinal plants.

\section{INTRODUCTION}

The south-western part of Nigeria is a vast area of rainforest with a high diversity of plants. Small scale farmers in the region use traditional shifting cultivation system to produce over $80 \%$ of the food they required (Leaky and Ladipo, 1996). Many rural families in the zone rely so much on wild fruits as food supplement, food condiments and medicinal plants for their health needs (WHO, 2003). Studies conducted in West African sub-region and other areas in the tropics have indicated that products of indigenous trees are marketed locally on a small scale to generate income to supplement a subsistent farming lifestyle (Falconer, 1990). Most of these products are frequently collected in the natural forests or from wild trees retained on farmlands and are well traded on regional and international markets. The list of these non-timber forest products (NTFPs) is not exhaustible and it depends on geographical regions and climate which dictate the type of vegetation of an area. Simon (1981) observed that the availability of these products depends on environment and that they satisfy different needs in many parts of the world. As a result of the availability these NTFPs low value is placed on them, they are abused, misused and mismanaged. Market studies have demonstrated a strong demand for NTFPs in the humid forests of southwestern Nigeria. Examples of such include Crysophyllum albidum, 
Ricinodendron heudelotii, Irvingia gabonenesis, Gnetum africanum and a host of other medicinal plats (Uzo, 1980). Medicinal plants are used to cure some diseases and sickness like mental disorder, malaria fever, sickle cell anaemia, convulsion, rheumatism, etc. This study was, therefore, undertaken to determine the demand and market pattern of some selected medicinal plants in the southwestern Nigeria.

\section{MATERIALS AND METHODS}

The study area comprised of Oyo, Ekiti and Ogun states all in the south western part of Nigeria. The population in these states is dominated by Yoruba with the mixture of other ethnic groups and foreigners who had settled down especially in the state capitals. Structured questionnaires containing both open and close ended questions were administered to obtain primary information. Questionnaire administration was also supplemented with oral interview using the participatory method for the buyers and suppliers of the medicinal products. Purposive stratified random sampling technique was used in selecting the local governments in each of the states based on the availability of the targeted respondents in the study area. A total of 405 questionnaires were administered giving a total of 135 for each of the selected states. Information was obtained on the source of the medicinal plants, needs for the selected plants, trends of demand and supply of the medicinal plants in the study area. The data collected were subjected to both descriptive and inferential statistical analyses. Descriptive statistical techniques such as percentages and frequency counts were used to analyse the demographic variables while inferential statistics such as chi-square was used to analyse the data.

\section{RESULTS}

The study revealed that majority of the respondents fell in the age group of 51 and above (Table 1), while 20.55\%, $24.43 \%$, $8.68 \%$ represented age groups 41-50, 31-40 and 21-30 respectively. Small percentages of the respondents $(2.51 \%)$ fell within 1-20 years of age. In the study area, $45.48 \%, 12.80 \%$ and $5.74 \%$ of respondents attended primary, secondary and tertiary schools respectively while $35.98 \%$ had no formal education (Table 1). The source of medicinal plants for marketing and utilization in the study area is shown in Table 3. The sources of medicinal plants for the majority of the respondents are the natural forests. For instance, $68.57 \%$, $11.65 \%, 9.67 \%$ and $3.30 \%$ of the respondents obtained their products from the natural forest, secondary forest, family farm and fallow land respectively. The rural people in the study area depend directly on Afromomum melegueta, Garcina kola, Senna alata, Tetrapleura tetrapetra, and Piper guineense as major active ingredients in herbal preparations. Food condiments and incorporated medicinal plant species had $43.08 \%$ and $44.62 \%$ respectively by the respondents for daily use. Lower percentage of the respondents $(12.31 \%)$ relied on western drugs mainly because of their educational status and/or income level. The market patterns and the nature of demand for medicinal plants in the study area showed are shown in Table 3. About 64.79\%, 22.66\%, $3.81 \%$ and $8.74 \%$ of the respondents indicated daily, weekly, annual and periodic markets respectively. Pearson chi-square of 9.95 at probability level of 0.05 indicates that there is no significant difference between the marketing patterns among the states in the study area (Table 6). Regarding the frequency of demand for medicinal plants, a high percentage $(81.37 \%)$ of marketers indicated that medicinal plants are always on high demand by users while small percentage $(18.69 \%)$ of the marketers indicated that medicinal plants are rarely demanded (Table 3 ). The result of the surveys showed that all plant parts are useful and always on demand across the study area (Table 3 ). The finding indicated that over $80 \%$ of the respondents offered all plant parts (leaf, stem, bark, root,fruit and seed) for sale. Chi-square of 46.6 at probability level of 0.05 showed that plant parts sold depend on the location. 
Table 1: Age distribution and literacy level of the respondents.

\begin{tabular}{lccccc}
\hline Age group (yrs) & Ogun & Ekiti & Oyo & Total & Percentage \\
\hline $\mathbf{1 - 2 0}$ & 0 & 0 & 11 & 11 & 2.51 \\
$\mathbf{2 1 - 3 0}$ & 15 & 11 & 12 & 38 & 8.68 \\
$\mathbf{3 1 - 4 0}$ & 39 & 23 & 45 & 107 & 24.43 \\
$\mathbf{4 1 - 5 0}$ & 28 & 34 & 28 & 90 & 20.55 \\
$\mathbf{5 1}$ above & 64 & 73 & 55 & 192 & 43.84 \\
Total & $\mathbf{1 4 6}$ & $\mathbf{1 4 1}$ & $\mathbf{1 5 1}$ & $\mathbf{4 3 8}$ & $\mathbf{1 0 0}$ \\
Literacy level & & & & & \\
No formal education & 48 & 71 & 44 & 163 & 35.98 \\
Primary school & 80 & 50 & 76 & 206 & 45.48 \\
Secondary school & 20 & 17 & 21 & 58 & 12.80 \\
OND & 6 & 4 & 11 & 21 & 4.64 \\
HND & 0 & 1 & 4 & 5 & 1.10 \\
Total & $\mathbf{1 5 4}$ & $\mathbf{1 4 3}$ & $\mathbf{1 5 6}$ & $\mathbf{4 5 3}$ & $\mathbf{1 0 0}$ \\
\hline
\end{tabular}

Table 2: Sex distribution of the respondents.

\begin{tabular}{lcccccc}
\hline Sex & Ogun & Ekiti & Oyo & Not specified & Frequency & Percentage \\
\hline Female & 119 & 138 & 140 & - & 397 & 8.25 \\
Male & 8 & 9 & 5 & - & 22 & 12.74 \\
Not specified & - & - & - & 36 & 36 & 7.9 \\
Total & $\mathbf{1 2 7}$ & $\mathbf{1 4 7}$ & $\mathbf{1 4 5}$ & $\mathbf{3 6}$ & $\mathbf{4 5 5}$ & $\mathbf{1 0 0}$ \\
\hline
\end{tabular}

Table 3: Market pattern, demand and parts of medicinal plants sold.

\begin{tabular}{lccccc}
\hline Market pattern & Ogun & Ekiti & Oyo & Total & Percentage \\
\hline Daily & 105 & 96 & 88 & 289 & 64.79 \\
Weekly & 32 & 24 & 45 & 101 & 22.66 \\
Annually & 3 & 6 & 8 & 17 & 3.81 \\
Periodic & 11 & 14 & 14 & 39 & 8.74 \\
Total & $\mathbf{1 5 1}$ & $\mathbf{1 4 0}$ & $\mathbf{1 5 5}$ & $\mathbf{4 4 6}$ & $\mathbf{1 0 0}$ \\
Demand for medicinal plants & & & & & \\
Always & 127 & 111 & 123 & 361 & 81.31 \\
Rarely & 23 & 29 & 31 & 83 & 18.69 \\
Total & $\mathbf{1 5 0}$ & $\mathbf{1 4 0}$ & $\mathbf{1 5 4}$ & $\mathbf{4 4 4}$ & $\mathbf{1 0 0}$ \\
Plant parts sold & & & & & \\
Leaf & 1 & 2 & 3 & 6 & 1.43 \\
Roots & 8 & 3 & 15 & 26 & 6.19 \\
Bark & 3 & 0 & 18 & 21 & 5.01 \\
Fruits and seeds & 4 & 18 & 8 & 30 & 7.14 \\
All the parts & 123 & 109 & 105 & 337 & 80.23 \\
Total & $\mathbf{1 3 9}$ & $\mathbf{1 3 2}$ & $\mathbf{1 4 9}$ & $\mathbf{4 2 0}$ & $\mathbf{1 0 0}$ \\
\hline
\end{tabular}


Table 4: Average daily patronage and source of the plants.

\begin{tabular}{lcc}
\hline Average daily patronage & Frequency & Percentage \\
\hline $\mathbf{1 - 1 0}$ & 54 & 11.87 \\
$\mathbf{1 1 - 2 0}$ & 161 & 35.38 \\
$\mathbf{2 1 - 3 0}$ & 100 & 21.98 \\
$\mathbf{3 1 - 4 0}$ & 49 & 10.77 \\
$\mathbf{4 1}$ above & 86 & 18.90 \\
Not specified & 5 & 1.10 \\
Total & $\mathbf{4 5 5}$ & $\mathbf{1 0 0}$ \\
Source of supply & & \\
Supplier & 26 & 5.71 \\
Family farm & 44 & 9.67 \\
Fallow land & 15 & 3.30 \\
Secondary forest & 53 & 11.65 \\
Natural forest & 312 & 68.57 \\
Not specified & 5 & 1.1 \\
Total & $\mathbf{4 5 5}$ & $\mathbf{1 0 0}$ \\
\hline
\end{tabular}

Table 5: Different uses of the plants.

\begin{tabular}{lccccc}
\hline Preferential use of medicinal plants & Ogun & Ekiti & Oyo & Total & Percentage \\
\hline Spice only & 62 & 58 & 76 & 196 & 43.08 \\
Spice and medicinal plants & 64 & 71 & 68 & 203 & 44.62 \\
Orthodox drugs & 19 & 15 & 22 & 56 & 12.31 \\
Total & 145 & 144 & 166 & 455 & 100 \\
Reasons for using medicinal plants & & & & & \\
Active ingredient in local concoction & 142 & 115 & 130 & 387 & 85.05 \\
Non active in local concoction & 28 & 25 & 15 & 68 & 14.95 \\
Total & 170 & 140 & 145 & 455 & 100 \\
\hline
\end{tabular}

Table 6: Chi - square test result.

\begin{tabular}{lcccc}
\hline Respondents' & $\mathbf{X}^{2}$ cal & $\mathbf{X}^{2}$ tab & $\mathbf{d f}$ & Remark \\
\hline Gender vs. utilization of medicinal plants & 9.95 & 12.59 & 6 & Not significant \\
Marketing pattern vs. utilization & 22.84 & 21.03 & 12 & Significant \\
Utilization vs. sources of supply & 13.25 & 9.49 & 4 & Significant \\
Needs vs. prevalence of medicinal plants & 43.77 & 12.59 & 6 & Significant \\
\hline
\end{tabular}

\section{DISCUSSION}

The age group of the marketers involved in the marketing medicinal plant products was the active, hale and hearty people that possess the required strength and vigour to face the stress involved in the distribution of the product. It was also evident that majority of the respondents were female which agreed with the findings of Popoola and Oluwalana (1998). Persson (1986) asserted to 
the fact that the business of forest products usually classified as minor was always in the hands of women. Women were also specialized in collection, preparation and administration of medicinal plants due to their inherent knowledge of child caring from their mothers or elders. Literacy level of the respondents showed that majority of those in this business attended primary and secondary schools. Hedge et al. (1996) supported this finding that literacy level had a direct bearing on non-timber forest products such that those that were educated tend to have less preference for NTFPs business. This is probably why only small percentage of the marketers (5.74\%) who had a higher educational status partakes in the marketing of medicinal plants and participation may even be due to recent awareness on the importance of herbal medicine while majority are the less educated people. Findings also revealed that supply of medicinal plants are from the forest which would have direct bearing on the depletion and degradation of the forest ecosystem as the gatherers were not making any attempt to regenerate these non-timber forest products. Hence, medicinal plants were no longer available in nearby secondary forest and fallow land. The use of medicinal plant for curing ailments is very common among rural dwellers as it was discovered that over $80 \%$ of the respondents gathered their herbal requirement for curative purpose. Most of the respondents believed that selected plants were active in local concoction (Table 5) while $14.95 \%$ of the respondents had a contrary view. The preference of herbal remedies to orthodox drugs is attributed to the potency, availability, and less harmful effect of the former (Adekunle, 2005). Several plant parts such as bark, roots, leaves, fruits and seeds are usually offered for sale but the patronage depends solely on the taste and preferences of the buyers of the medicinal plant parts. Across the study area however, majority of the population undertake daily market patterns.
This is an indication that marketing of medicinal plants has been the source of their income, a pointer to high dependence on the trade for sustaining their livelihood.

\section{Conclusion}

The study has investigated the demand and market pattern of medicinal plants of Afromomum melegueta, Garcina kola, Senna alata, Tetrapleura tetrapetra, and Piper guineense from the selected study area in the south-western Nigeria. It was discovered from the study that medicinal plants have a great potential for employment creation, income generation and sustainability of the rural populace. The gatherers and marketers of these medicinal plants do harvest and sell all plant parts such as leaf, bark, root, fruits and seeds without considering any conservation strategies for regeneration. This action then leads to the depletion of these valuable plant parts which are utilized for curing different types of ailments. All hands must therefore be on deck to maintain the concept of sustainability for the continuous production of these medicinal plants and for continuous flow of income for those in the business of medicinal plant parts.

\section{REFERENCES}

Adekunle VAJ. 2005. Trends in forest reservation and biodiversity conservation in Nigeria: In Environmental Sustainability and Conservation in Nigeria, Okoko E, Adekunle VAJ, Adeduntan SA. (Eds). Environmental Conservation and Research Team. Federal University of Technology, Akure. Nigria; 82-90.

Falconer J. 1990. Non timber forest products in southern Ghana. A summary report ODA. Forestry, no. 2, Natural Resources Institute Cahtam, 53-73.

Hedge R, Suryapkrakash S, Choth LA, Bana, KS. 1996. Extraction of NTFPsin the forest of Biligiri Rangan Hills India: 
contribution of rural income. Economic Botany, 50: 243-251.

Leaky RRB, Ladipo DO. 1996. Trading on genetic variation of fruits of Dacroyodes edulis. Agroforestry Today, 8(2): 16 - 17.

Persson JK. 1986. Tree plants and the rural communities in southern Sudan. Unasylva, 154(38): 32-43.

Popoola L, Oluwalana, SA. 1998. Marketing of non- timber forest products in Nigeria. Paper presented at Colloquium on Biodiversity (Rainforest Ecosystem of Nigeria) Organised by FEPA-UNAAB linkage Centre for Forest Conservation and Biodiversity, 21.
Simon IG. 1981. Global resource. In Challenges of Interdependence, Glassness MI (Ed.). Praeges Publisher: New York; 230.

Uzo JO. 1980. Yield and harvest predictions of some indigenous perennial fruits, roots and leaves in tropical West Africa. Proceeding of international symposium on current problems of fruits and vegetables (Tropical and Sub-tropical). Laguna 24-26. March 1980. 22pp.

World Health Organization. 2003. Traditional Medicine. Fact sheet No. $134,1^{\text {st }}$ may $2003 ; 1-3$ 